\title{
René Antoine Ferchault de Réaumur (1683-1757), a naturalist and pioneer of acarology and his contacts with Poland
}

\author{
PIOTR DASZKIEWICZ \\ Institute for the History of Science, Polish Academy of Sciences, Nowy Świat 72, 00-330 Warsaw, \\ Poland; and National Museum of Natural History, 57 Rue Cuvier, 75005 Paris France; \\ e-mail: piotrdas@mnhn.fr
}

Corresponding author: Piotr Daszkiewicz, e-mail: piotrdas@mnhn.fr

(Received on 7 January 2016; Accepted on 12 July 2016)

\begin{abstract}
René Antoine Ferchault de Réaumur was one of the most important scientists of the Age of Enlightenment. His relations with Polish scientists are analysed, with particular reference to Franciszek Bieliński (Grand Marshal of the Crown), Konstanty Franciszek Fremel (a Saxon specialist of glass technology in Poland), and Johann Ernst Stieff (a Silesian scientist). Réaumur's work on mites is discussed in the context of his entomological publications. For the first time, illustrations of mites drawn by Claude Aubriet (from Réaumur's collection) are reproduced here.
\end{abstract}

\section{INTRODUCTION: RÉAUMUR'S SCIENTIFIC RESEARCH}

The 18th century marked a revolution in the natural sciences. The cabinets of curiosities, i.e. collections of natural history specimens, became more and more important then. Descriptions of those collections resulted in many zoological, mineralogical, and botanical works. Carl Linnaeus (1707-1778) proposed the new rules of nomenclature and systematics: it was the beginning of the modern taxonomic system that we still use today. The work of Antoine Lavoisier revolutionized chemistry. The Histoire naturelle, written in Paris by the naturalists of Jardin des Plantes, was the first large encyclopaedia of natural history. Microscopy and optical instruments became more and more sophisticated. The natural sciences attracted many enthusiasts, including politicians and philosophers, such as Jean-Jacques Rousseau (1712-1778).

René Antoine Ferchault de Réaumur (see Fig. 1) occupies a very special position in the history of science in the Age of Enlightenment. He was a rare French naturalist of the 18th century who was not a physician by training but a mathematician and physicist. Very early, at the age of 28 years, he became a member of the Royal Academy of Sciences. Today, he is probably best known as the inventor of an alcohol 


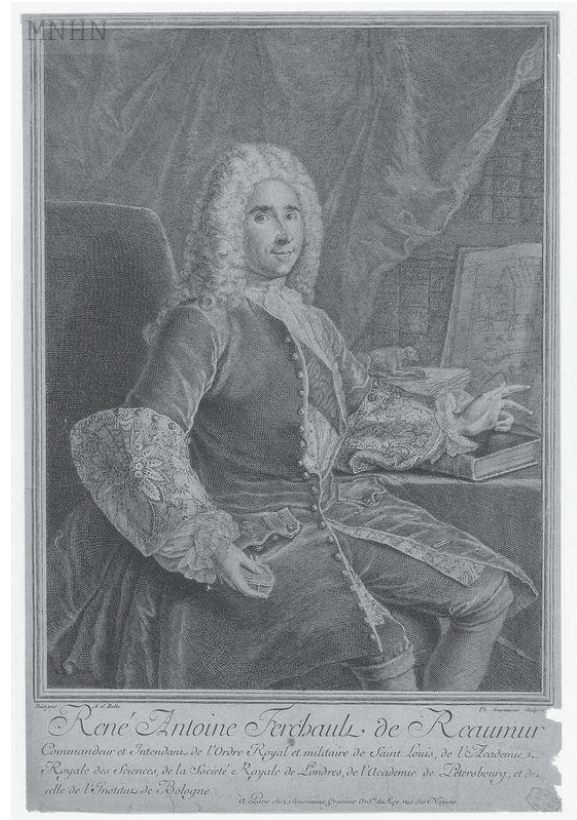

Fig. 1. Portrait of René Antoine Ferchault de Réaumur (engraved by Philippe Simonneau after a painting by Alexis Simon Belle, collection of National Museum of Natural History, Paris).

thermometer and the author of the temperature scale called now 'Réaumur scale' (BIREMBAUT 1958). The fields of his research, however, were very wide even for the 18th century: from geometry to mineralogy, gold and turquoise mining, production of iron and steel, as well as natural history. He was the first to show the amount of carbon in iron. He was interested in forest policy and prepared a report on the destruction of forests in France. In response to a request of the royal administration, he also studied the technology of production of porcelain, mirrors, pearls, and chalk (ToRLAIS 1961), and elaborated a system of artificial incubation of eggs. Réaumur influenced also French scientific politics as the author of the Reflections on the utility of which the Academy of Sciences in the Kingdom could be, if the Kingdom gave it the means it needs. Much of his work focused on natural history. He obtained important results in ornithology, entomology, arachnology, embryology, physiology, and genetics. In 1710 he wrote a paper on the possibility of spiders being used to produce silk. $\mathrm{He}$ became famous through this work.

Réaumur created a rich cabinet of curiosities, a veritable museum of natural history. His collection was one of the largest in Europe. His museum's conceptions were very modern. Not only he devoted several works to the art of taxidermy, but he also stressed that such collections should be used for research and as scientific working tools. Réaumur attached great importance to represent wildlife with at least one specimen of each species, with information on their habitat and habits. 


\section{RELATIONS WITH POLAND}

Réaumur influenced all generations of French naturalists, but his educational work was also important for the history of natural sciences in Poland. For example, Réaumur's student, Jean-Étienne Guettard (1715-1786), spent 2 years (1760-1762) in our country, conducting research on the natural history of Poland and Lithuania. His work resulted in a first geological map, a scientific description of the salt mine of Wieliczka, as well as many palaeontological, botanical, meteorological, and medical observations. Another student and close associate of Réaumur, Mathurin Jacques Brisson (1723-1806), was one of the most important teachers of Stanisław Staszic, a leading figure in the Polish Enlightenment.

Réaumur was one of the first French scientists to set up a European network of correspondents. The letters and specimens sent by them enabled him to gather collections and naturalists' observations from all over Europe. At that time the Commonwealth of Poland and Lithuania covered an area of around $10^{6} \mathrm{~km}^{2}$. The cabinets of natural history created by Princess Anna Jabłonowska (1728-1800) or naturalists of Gdańsk were among the largest in Europe. Scientific relations between Poland and France were very strong, as many Poles came to study in Paris. The King of Poland donated a collection to the Paris Natural History Cabinet. However, the nature of this vast country was very poorly known and the work of a Jesuit priest, Gabriel Rzączyński (1644-1737), was often the only source of information (FEDOROwICZ 1966).

Réaumur's scientific correspondence, preserved at the Academy of Sciences in Paris, shows that he remained in contact with several Poles (DAszKIEwICZ 2009), but mostly with Franciszek Bieliński (1683-1766), Grand Marshal of the Crown. He is known mostly because of the political, economic, and military activity of this great magnate. He distinguished himself as an excellent administrator of the city of Warsaw, which owes him a deep modernization. The political activity of Bieliński was closely linked to French interests. He was one of the most important advisors of the French secret services in Poland. He even tried to organize a private army, financed by France. For this purpose in 1747 he travelled to Paris, where he met Réaumur.

His 3 letters preserved in the Fonds Réaumur in the archives of the Academy of Sciences in Paris, show another face of Bieliński: that of a naturalist and curious scientist. His first letter, sent from Warsaw on 26 June 1748, deals only with ornithological issues. The species mentioned were, in the imagination of naturalists of the $18^{\text {th }}$ century, linked to Poland. The first one was the snow bunting Plectrophenax nivalis, an Arctic bird, wintering regularly in Poland at that time, best known to European naturalists of our country and Sweden. French scholars were then unaware of its presence in France, hence the interest of Réaumur and his will to have its specimen in his office. That letter was accompanied by specimens of not only this species but also of the European penduline tit, Remiz pendulinus, which in the $18^{\text {th }}$ century was considered to be a typical Polish bird. The majority of information on the latter species came from Poland and Lithuania. Its unique nest, boot-shaped woven and hanging from branches of trees, aroused interest among curiosity naturalists and was particularly sought after by collectors. This mysterious bird was the subject of vari- 
ous publications and press releases sent to the Royal Academy of Sciences and scientific societies in different countries. In France, European penduline tit's nests were among the greatest naturalists' rarities. Bieliński sent to Paris the bird and its nest. He also sent his notes about both bird species and about wintering swallows. His second letter was sent to Réaumur almost a year after the first one, on 3 May 1749. It was written in Otwock, where Bieliński had important properties. It is fully dedicated to a very detailed description (probably one of the most detailed in the $18^{\text {th }}$ century) of the mode of reproduction of locusts, with a description of the laying and burying of eggs in the soil, morphological details of the female organs related to oviposition, and the emergence of juveniles. Bieliński sent also to Paris locust eggs. His third letter was sent from Warsaw 5 years later, on 21 December 1754. The letter accompanied a specimen of a mineral ("a hard mass and heavy") obtained from the Bishop of Krakow. He decided to offer it as a gift to Réaumur's cabinet.

A letter from Konstanty Franciszek Fremel is also preserved in the archives of Réaumur, and another letter was sent to him by his daughter, after the father's death. Fremel was one of the major European glass manufacturers of the Age of Enlightenment. The correspondence focused on the technology of mirror production.

One of Réaumur scientific correspondents was also the physician Johann Ernest Stieff (1719-1793), who lived in Breslau (now Wrocław in Poland). His letters, sent on 28 January 1750 and 15 August 1755, are interesting documents related to the history of Silesian science. Stieff touched upon various subjects, expressed interest in several editions of the Histoire des Insectes, informed about the uses he made of Réaumur's thermometer, and presented his observations and interpretations of thunderbolts and lighting, linking the increase in the number of thunderstorms with volcanic activity in southern Europe. He enclosed a list of 19 minerals and fossils he had sent to Paris, including their description and a precise location of their origin. This is probably the oldest known document concerning the submission of Silesian natural history specimens to France (DASZKIEWICZ \& TARKOWSKI 2011).

We can also assume that Réaumur corresponded with Jacob Theodor Klein (1685-1759), the famous naturalist of Gdańsk. The French translation of his book on sea urchins and belemnites, Ordre naturel des oursins de mer et fossiles: avec des observations sur les piquans des oursins de mer, et quelques remarques sur les bélemnites, was enriched by illustrations from Réaumur's collection. A letter to Klein is preserved at the Polish Academy of Sciences in Gdańsk. Nevertheless, in the Parisian archives no other traces of this collaboration were found.

\section{PIONEER OF ENTOMOLOGY AND ACAROLOGY}

Réaumur was passionate about entomology. He is considered to be one of the most important pioneers of this branch of zoology and father of entomology in France. CARTON (2005) rightly points out that the Age of Enlightenment was a period of great advances in many scientific fields but for entomology this time was rather an "age of darkness":

"the insect kingdom being all but ignored in L'Encyclopédie, ou Dictionnaire Raisonné des Sciences des Arts et des Métiers (the most famous French report 
on all the sciences, published from 1751 to 1772 , in 28 volumes) of D. Diderot (1713-1784) and Jean-le-Rond d'Alembert (1717-1783). Only six pages out of 18,000 are devoted to insects (including the chelicerates!). Insects are similary neglected in the Histoire Naturelle of Georges Louis Leclerc, Comte de Buffon (1707-1788)." (CARTON 2005:41)

In this unfavourable context for research on the insects, Réaumur published, from 1734 to 1742, in six volumes the Mémoires pour servir à l'histoire des insects, a true entomological encyclopaedia. His work was pioneering in various fields of entomology, even though he was interested mainly in insect behaviour and physiology. Réaumur studied and described the effects of temperature on the time needed for insects to develop and resistance to low temperature (RosTAND 1962). Réaumur's book was the most important treatise on bees in the $18^{\text {th }}$ century. He described Braula caeca, a dipterous ectoparasite of bees, and reported that inside the queens of bumble bees (Bombus) he found and illustrated clusters of worms (EGERTON 2006). He was the first in France to describe and make many comments on the parasitic wasps: oviposition behaviour of the female, larval diapause, feeding behaviour of the parasitoid larvae, prevalence of parasitism in the field, gregarious behaviour, control of crop pest populations by parasitoids, ectoparasitic and endoparasitic species (CARTON 2005). Besides, Réaumur studied the physiology and behaviour of gall-inducing insects. He was also the author of many valuable observations on ants, e.g. the first information about ants mating (Drouin 1987).

In the $18^{\text {th }}$ century, mites were still classified as insects. Réaumur was particularly interested in this group. He was the first to describe several species of Riccardoella, which are parasitic mites of snails (RÉAUMUR 1710). He intended to use this parasitism to protect crops. Today he is considered a precursor of biological control. He observed and described also mites in galls of various species of trees. UECKERMANN (2010) noted:

"The first reference to eriophyoids was apparently made by RÉAUMUR (1737) who referred to galls and erinea caused by arthropods. He described them as maggots which was more correct than subsequent taxonomists who considered them fungi." (UECKERMANN 2010:1)

The merits of Réaumur for acarology are not limited to the description of mites and their behaviour. He was one of the first naturalists who discussed the general concept of "insect" (DrouIN 2014) and challenged the Aristotelian system. Thus he prepared the ground for the separation of arachnids from insects. The emancipation of acarology as a distinct branch of zoology was the work of French naturalists belonging to the next generation: Jean-Baptiste Lamarck (1744-1829) and Pierre-André Latreille (1762-1833). They were followers of the work of Réaumur.

\section{UNPUBLISHED ACARALOGICAL DOCUMENTS}

Réaumur did not succeed to finish his work Mémoires pour servir à l'histoire des insects. The volume that was supposed to include mites has never been written. I did research in the archives of the Academy of Sciences and the National Museum of Natural History in Paris to find Réaumur's documents linked to the history of acarol- 
ogy. In the archives of the Academy of Sciences we found some pages bearing the title "acariens" (mites) and "ricin ou ticques" (ticks), describing the ticks, the storage mites, and some mite parasites of trees.

The Central Library of the Paris National Museum of Natural History has a collection of illustrations that were in the past property of Réaumur. Three of these drawings show mites. They were authored by Claude Aubriet (1665-1742), an official naturalist illustrator of the King of France. These drawings were probably intended to illustrate a volume of Mémoires pour servir à l'histoire des insects. They represent ticks (Figs. 2 and 3) with anatomical details (stigma and genital opening), a mite species of the family Acarididae and a species of Hydrachnidia (water mite, see Fig. 4). These drawings, important for the history of zoology, have never been published so far. I present them here for the first time with a kind permission from the National Museum of Natural History in Paris.

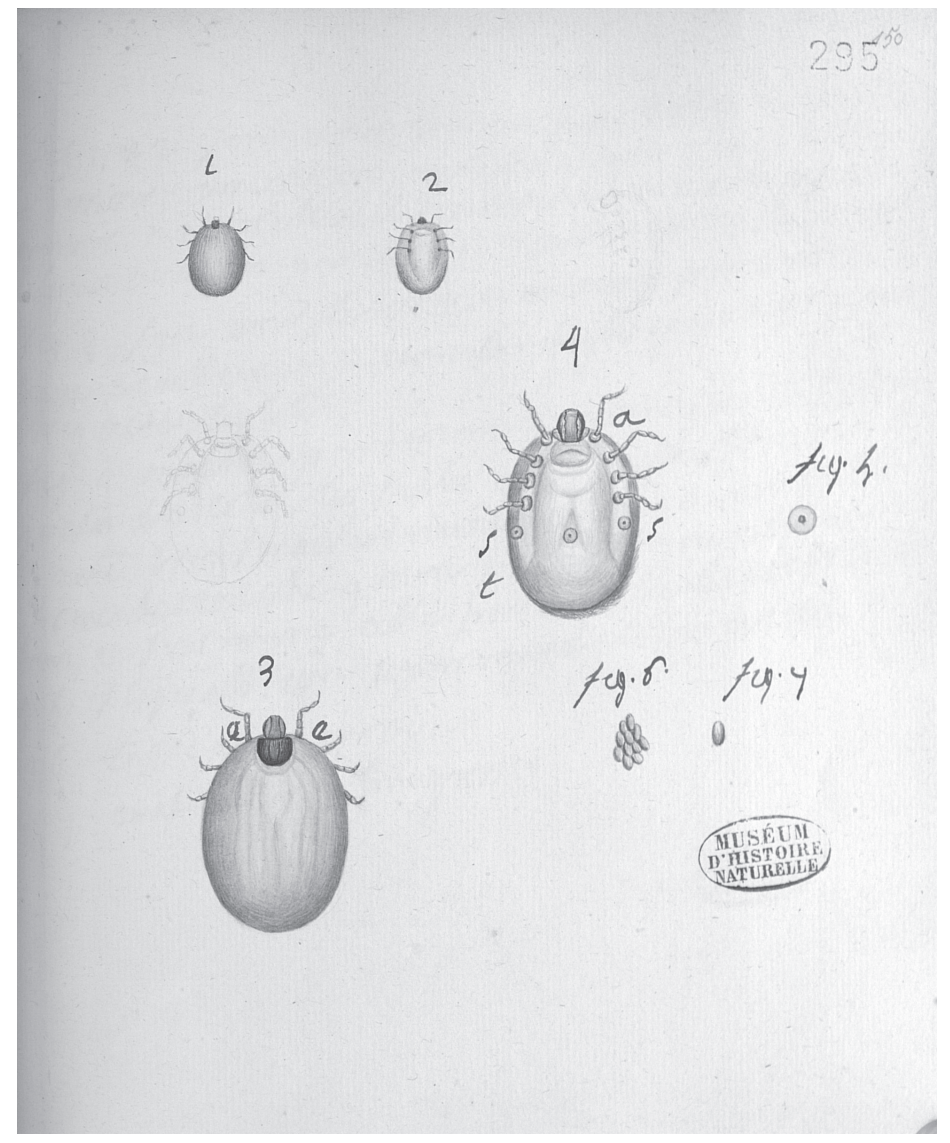

Fig. 2. Ticks, probably female (engorged), with visible right and left stigma and genital aperture (4), magnified stigma (5), and eggs (6 and 7) (drawings by Claude Aubriet, collection of National Museum of Natural History, Paris) 00098.pdf 


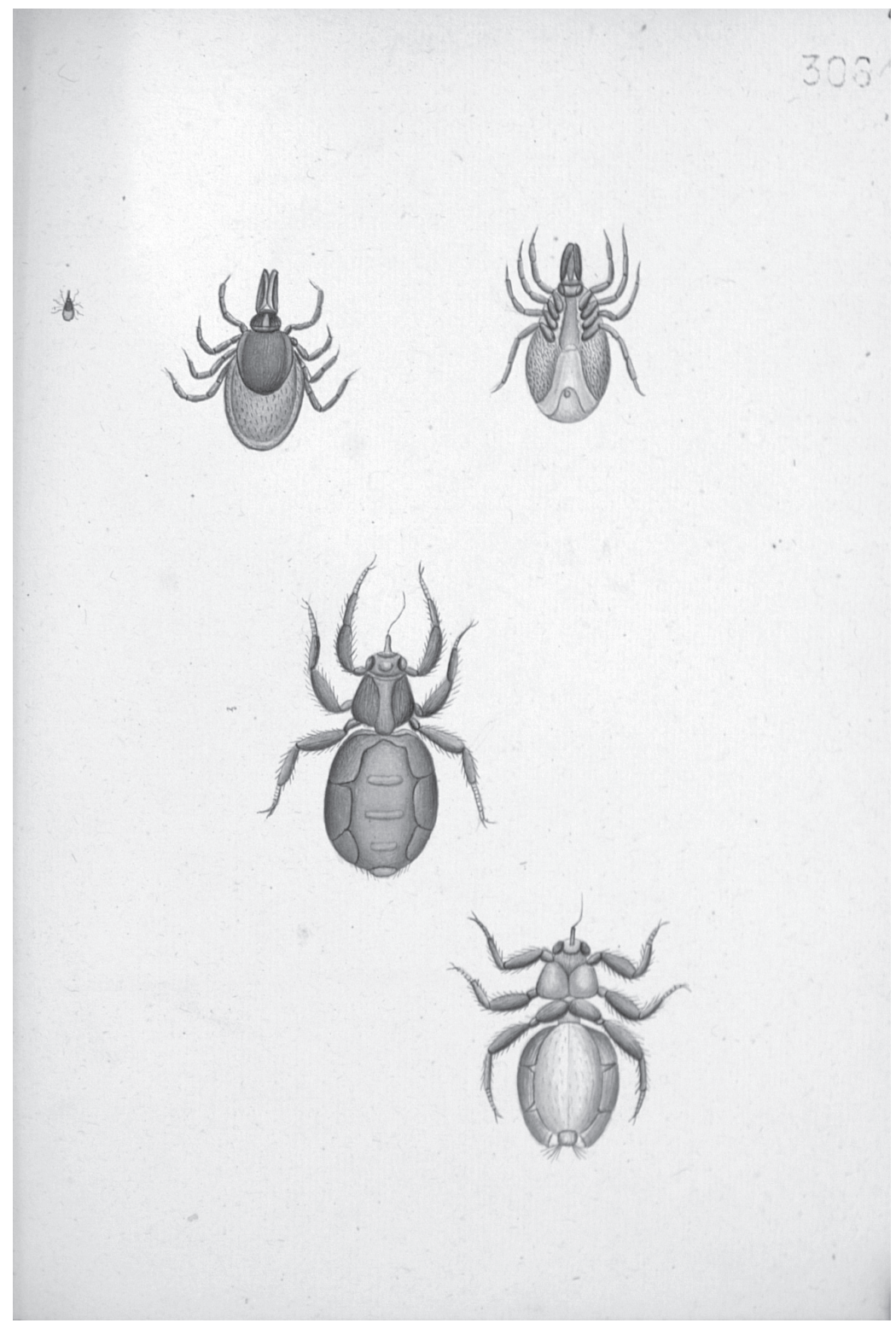

Fig. 3. Ticks, probably Ixodes ricinus, female (not engorged), from left to right: natural dimensions, dorsal view, ventral view (with pedipalps and hypostome); below, probably louse flies (drawings by Claude Aubriet, collection of National Museum of Natural History, Paris) 


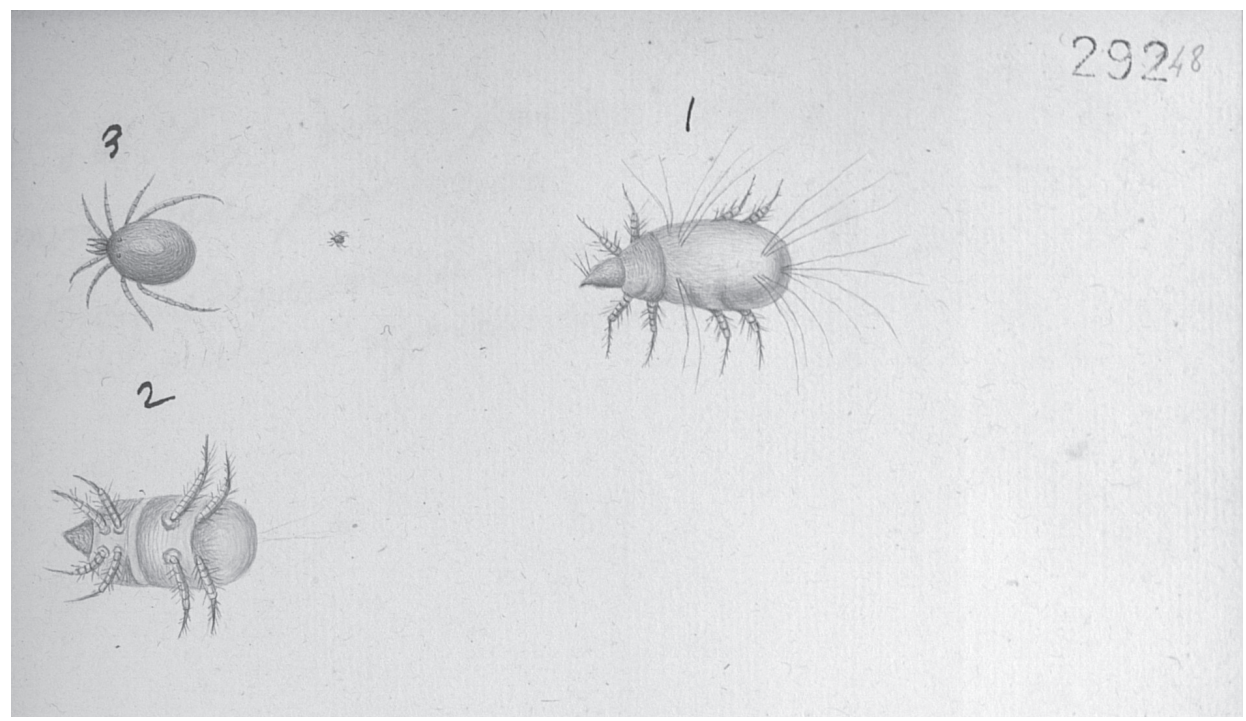

Fig. 4. A mite of the family Acarididae (1 and 2) and a water mite (Hydrachnidia, 3) with very good representation of eyes (drawings by Claude Aubriet, collection of National Museum of Natural History, Paris)

\section{CONCLUSIONS}

The life and work of Réaumur was the subject of many studies and publications. History has done justice to him already in the 19th century. In 1877, on the occasion of the presentation of an honorary LL.D degree to Charles Darwin, Thomas H. Huxley commented: "I know of no one who is to be placed in the same rank with [Darwin] except Réaumur" (Huxley 1900, EGERTON 2006). Yet we are still discovering the importance of his work in the history of biology. Some aspects of this work are little known. His relations with Poland and their contribution to the history of research on mites undoubtedly deserve further studies.

Acknowledgments: I am grateful to Prof. Jacek Dabert, head of the Department of Animal Morphology of Adam Mickiewicz University in Poznań, for help in interpretation of the iconography, and to Pascale Heurtel, curator of the library of National Museum of Natural History in Paris for help in research on the old documentation.

\section{REFERENCES}

Birembaut A. 1958. La contribution de Réaumur à la thermométrie. Revue d'Histoire des sciences et de leurs applications $11: 302-329$. 
CARTON Y. 2005. Réaumur (1683-1757): the discoverer of parasitoids in France. Biol. Control. 32: $40-48$.

DAszKIEwicz P. 2009. Polonika w archiwum René-Antoine Ferchault de Réumura (1683-1757). KHNiT. 54: 83-93.

Daszkiewicz P., TaRkowski R. 2011. Listy Johanna Ernesta Stieffa (1719-1793) do René-Antoine Ferchaulta de Réaumura (1683-1757) w archiwach Francuskiej Akademii Nauk - nieznany interesujący dokument historii śląskiej geologii. Przegląd Górniczy 1-2: 84-87.

Drouin J.-M. 1987. Du terrain au laboratoire : Réaumur et l'histoire des fourmis. Aster 5: 35-47.

Drouin J.-M. 2014. Philosophie de l'insecte. Editions du Seuil. Paris.

Egerton F. N. 2006. A history of the ecological sciences, Part 21: Réaumur and his history of insects. Bull. Ecol. Soc. Am. 87: 212-224.

Fedorowicz Z. 1966. Fauna Polski w dziełach o. Gabriela Rzączyńskiego T. J. (1664-1737). Mem. Zool. 16: 220.

Huxley L. 1900. Life and letters of Thomas Henry Huxley. Vol I. Macmillan, London, UK.

Réaumur R. A. F. De. 1710. Insecte des limaçons. Mémoire de l'Académie des Sciences 8: 305-310.

Rostand J. 1962. Réaumur et la résistance des insectes à la congélation. Revue d'd'histoire des sciences et de leurs applications, 71-72 (in French).

Torlais J. 1961. Un esprit encyclopédique en dehors de «L'Encyclopédie». Libraire scientifique et technique A. Blanchard. Paris.

Ueckermann E. A. 2010. Eriophyoid mites: progress and prognoses. Exp. App. Acarol. 51: 1-30. 